\title{
ŚW. BRYGIDA - CYKL OBRAZÓW W KOŚCIELE PW. WNIEBOWZIĘCIA NMP ZWYCIĘSKIEJ W LUBLINIE
}

W pierwszej poł. XVII w., za czasów ksieni Doroty Firlejówny, w prezbiterium kościoła brygidek lubelskich zostały wprowadzone stalle (il. 1), jako jeden z elementów nowego wyposażenia, obok ołtarzy, stall w kaplicy bocznej oraz stiuków na sklepieniu. Zaplecki stall prezbiterium zostały ozdobione obrazami ukazującymi epizody z życia św. Brygidy Szwedzkiej. Jak przekonują analizy ikonograficzne $^{1}$ dobór wydarzeń nie był przypadkowy, miały one uzasadniać, że sam Bóg przewidział Brygidę do wyjątkowych zadań w Kościele. Istniała w planach bożych jeszcze przed narodzinami - świadczy o tym pierwsze przedstawienie (il. 2), w którym widzimy jej ciężarną matkę, w sposób cudowny uratowaną z katastrofy morskiej ze względu na dziecko, które nosiła w swoim łonie. Tuż po rozwiązaniu Maryja sama ogłosiła proboszczowi miejscowej parafii, o czym dowiadujemy się z drugiego przedstawienia (il. 3), że nowo narodzona dziewczynka jest wyjątkowa, i że ,jej głos przedziwny po całym świecie będzie słyszany² w przybytkach sprawiedliwych"3, czyli w klasztorach brygidiańskich, o tym świadczy sylwetka kościoła brygidek lubelskich w tle kompozycji. Brygida od wczesnych lat swojego życia obdarzona była łaską bezpośredniej rozmowy z osobami boskimi: gdy

* Lidia Kwiatkowska-Frejlich - dr historii sztuki, adiunkt w Instytucie Kulturozawstwa UMCS, e-mail: lidiafrejlich@hektor.umcs.lublin.pl

${ }^{1}$ Szczegółowe opracowanie tego problemu czytelnik znajdzie w książce: L. Kwiatkowska-Frejlich, Funkcje potrydenckiej sztuki kościelnej. Nowożytny wystrój kościoła brygidek w Lublinie, Lublin 2009, s. 135-191.

${ }^{2}$ Skarby Niebieskich Taiemnic to iest Księgi Obiawienia niebieskiego Świętey Matki Brygitty Z rodzaju Królewskiego Xiężney Nerycki ze Szwecyey Fundatorki Reguly S. Salvatora z łacinskich na polskie przełożone przez zakonnika Braci Mniejszych Oyców Bernardynów za pozwoleniem starszych, Zamość 1698, k. 12 v.

${ }^{3}$ Poczyna się żywot skrócony ukochaney Oblubienice Chrystusowey ś. Brygitty, z krolestwa szwedzkiego, zawieraiacy w sobie pewne Obiawienia Boskie z niektorymi cudami, w: Skarby Niebieskich Taiemnic, s. 749. 
przyjęła z rąk Maryi koronę niebieską (il. 4), gdy ukazał się jej Chrystus Ukrzyżowany (il. 5) oraz gdy Jezus powiedział do niej, że ujrzy tajemnice niebieskie (il. 6). Chrystus również podyktował jej regułę zakonu Najświętszego Zbawiciela (il. 7). Dokonało się nawet małżeństwo duchowe Brygidy z Jezusem (il. 8). Kolejna scena cyklu: Święta Brygida w otoczeniu świętych w obecności Boga Ojca (il. 9) ma charakter symboliczny. Ilustruje warunki dostąpienia zbawienia przez człowieka, który realizuje drogę duchowości brygidiańskiej.

W tym miejscu narracja cyklu urywała się, gdyż znajdował się tu obraz ołtarza głównego, ukazujący Wniebowzięcie Maryi (il. 10). Następne przedstawienie stall to Drzewo genealogiczne św. Brygidy (il. 11) również o charakterze symbolicznym. Zamyka ono pierwszy etap jej życia, które wiodła w rodzinnej Szwecji, gdy była matką i żoną. Ten okres był dla świętej - o czym mówi obraz - powodem dumy i chwały, podobnie jak ten, który rozpoczęła w Italii. Wraz z córką miały tam żyć jak zakonnice. W obrazie tym zawarto ponadto informację, że św. Brygida przekazała mniszkom swego zakonu regułę zakonną, potwierdzoną swoim życiem, stając się $\mathrm{w}$ ten sposób dla nich wzorem do naśladowania. Pomimo wszystkich łask, którymi Bóg ją obdarował, święta wciąż pracowała nad sobą. Zdobyła wysoki poziom doskonałości ewangelicznej, o czym mówi druga część cyklu. Rozpoczyna się ona dwoma obrazami o podobnej tematyce (il. 12) św. Brygida i jej córka Katarzyna, wyruszają jako pielgrzymi do Rzymu. Dla nich jest to jednoznaczne z wkroczeniem w życie zakonne. Kolejny obraz w cyklu Adoracja krzyża przez śś. Brygidę i Katarzyne (il. 13) w sposób symboliczny obrazuje bramę wiodącą do klasztoru oraz warunki doskonałości brygidiańskiej. Następne sceny mówią o praktykach ascetycznych św. Brygidy, przypominają o tym, że podejmowała trud pielgrzymek, często rozważała Mękę Chrystusa, a jej modlitwy były „długie i ustawiczne” (il. 14), że umartwiała swoje ciało, m.in. w każdy piątek parzyła sobie ręce gorącym woskiem świecy (il. 15), praktykowała cnotę miłosierdzia: rozdawała biednym pieniądze, odwiedzała więźniów (il. 16). Kolejny obraz cyklu to scena śmierci św. Brygidy (il. 17). Ostatnie przedstawienie: Święta Brygida przygotowujaca swoja prawnuczke na śmierć, (il. 18) ukazuje jeden z cudów, który dokonał się za jej sprawą. Od dawna już nieżyjąca święta ukazała się swojej wnuczce, która oddana na naukę do cysterskiego klasztoru we Vreta śmiertelnie zachorowała. Dziewczynka widziała swoją babkę i za jej namową poprosiła zakonnice o poziomki. Była zima, więc zdziwiono się tej prośbie. Siostry jednak poszły tam, gdzie skierowała je dziewczynka i zebrały owoce. Siedząca w pobliżu łoża umierającej zakonnica to zapewne jedna z tych, o której była mowa w tekście żywota świętej, ma na sobie jednak habit brygidek, a nie - zgodnie z faktami historycznymi - cysterek. W taki oto plastyczny sposób ukazano związek Brygidy z zakonnicami swego zgromadzenia, w każdym pokoleniu. Ale obraz mówi przede wszystkim o bezwzględnym posłuszeństwie, słowom św. Brygidy.

Pierwotne siedemnastowieczne stalle już nie istnieją. Obecne, powstały w latach 1903-1910 w czasie prac renowacyjnych, które przeprowadził ówczesny rektor kościoła ks. Jan Władziński. Zachowano wszystkie siedemnaście obrazów,

${ }^{4}$ Skarby Niebieskich Taiemnic, ks. VII, rozdz. 13, s. 599-600. 
co potwierdzają zdjęcia archiwalne (il. 20). Nie wszystkie jednak znalazły się w nowych stallach, trzy umieszczono w ławkach nawy, a poza tym w nowe stalle obrazy wprawiono w sposób chaotyczny. Znamy jednak ich właściwą kolejność dzięki starym fotografiom. Od północy było ich osiem, od południa dziewięć. Pierwotnie stalle w prezbiterium z obu stron dochodziły do ołtarza głównego. Według Józefa Smolińskiego, który oglądał wnętrze kościoła przed zmianami, tworzyły „łącznie z wielkim ołtarzem rodzaj boazerii”. Ale stalle po prawej stronie nie mogły bezpośrednio stykać się z ołtarzem głównym, gdyż ,[...] blisko wielkiego ołtarza, nisko umieszczone, znajdowało się duże okratowane okno, dziś zamurowane, prowadzące do chóru zakonnego przez nie zakonnice słuchały Mszy św. i spowiadały się"6.

W kościołach brygidiańskich poszczególne przestrzenie były oddzielone od siebie. Przeznaczone były dla różnych grup modlących się w nich osób. Klasztor lubelski w średniowieczu funkcjonował - zgodnie z regułą zakonu Najświętszego Zbawiciela - jako podwójny, w którym żyła zarówno zakonna społeczność męska jak i żeńska7 . Jedynym miejscem bezpośredniego kontaktu brygidek i brygidów było to właśnie nisko usytuowane, zakratowane okno, ulokowane w ścianie prezbiterium, przez które zakonnice mogły się spowiadać i przyjmować komunię świętą, same niewidoczne z kościoła. Chociaż św. Brygida wiele pisała o wyglądzie kościołów swego zakonu, to jednak na podstawie jej tekstów nie możemy odpowiedzieć na pytanie: w jaki sposób miała być podzielona przestrzeń kościoła dla wszystkich, którzy z niego mieli korzystać. Pamiętajmy, że kościoły brygidiańskie zawsze były otwarte dla wiernych.

Podobnie w XVII w. różne grupy osób związane z kościołem lubelskim modliły się $w$ przestrzeniach dla siebie przeznaczonych ${ }^{8}$. Dlatego umieszczone w prezbiterium stalle ukazywały się im z innej perspektywy, a widząc różną ich część, były im przekazywane różne treści. Mniszki zajmowały, tak jak w średniowieczu chór górny, obecnie muzyczny, skąd widziały w prezbiterium przede wszystkim ołtarz główny z obrazem Wniebowzięcia Maryi, ponadto dwa przedstawienia $\mathrm{w}$ stallach, które jako jedyne oglądane były w pełnym widoku z takiej perspektywy. Były one większe od pozostałych obrazów cyklu ${ }^{9}$ mogły być dobrze widoczne z chóru, w którym zasiadały zakonnice. Boazeria, o której wspominał J. Smoliński, łączyła optycznie stalle z wielkim ołtarzem, sugerowała

${ }^{5}$ J. Smoliński, Kościót pp. Brygidek, później pp. Wizytek w Lublinie i odkryte malowidła ścienne z XV wieku, „Sprawozdania Komisji do Badania Historii Sztuki w Polsce”, 9 (1915) szp. 277.

${ }^{6}$ Tamże, szp. 278.

${ }^{7}$ Reguła S. Salwatora podana ś. Brygidzie z rewelacyj Xiag iej z łac. na polskie przettum. (Wiktoria Niemierzanka) z reguły Augustyna ś... ustawami zakonu tejże ś. Brygidy, Kraków 1673, s. 35.

${ }^{8}$ Kwiatkowska-Frejlich, Funkcje potrydenckiej sztuki kościelnej, s. 241-243.

${ }^{9}$ Wszystkie mają szerokość $32-39 \mathrm{~cm}$. Te dwa $51,5 \mathrm{~cm}$ i $53,5 \mathrm{~cm}$, przy czym, obrazy te zostały zmniejszone, przycięte prawdopodobnie podczas wprawiania ich w nowe stalle. Święta Brygida w otoczeniu świętych w obecności Boga Ojca (il. 9), święci ukazani w półpostaci wokół bramy ze swoimi atrybutami: św. Paweł - z mieczem, Jan Ewangelista - z orłem. Dwaj najwyżej umieszczeni w wyniku przycięcia obrazu są obecnie pozbawieni swoich atrybutów - prawdopodobnie jak poniżej ulokowani, mieli atrybuty od strony zewnętrznej obrazu. 
również łączność ideową tych trzech przedstawień. Literacką podstawą przedstawienia Święta Brygida w otoczeniu świętych w obecności Boga Ojca (il. 9) jest tekst z objawień świętej, który mówi, że zakonnica żyjąc w klasztorze przechodzi drogę doskonałości. W omawianym przedstawieniu droga ta została zilustrowana trzema stopniami wiodącymi do bramy niebios. Ułożone na pierwszym kolczaste gałązki symbolizują pokutę, ale też pokorę, która jest podstawą drogi duchowości brygidiańskiej. Na drugim pojawiają się róże - cierniste łodygi zakwitły kwiatami, które obrazują zdobyte już cnoty, ale ich kolce uzmysławiają, że człowiek tkwi jeszcze w grzeszności. Św. Brygida mówiła, że na tym etapie, w człowieku cnoty zaczynają górować nad wadami i jest już gotowy do postanowień, aby więcej grzechów nie popełniać i pielęgnować cnotę miłosierdzia. Trzeci stopień, niczym nie usłany, prowadzi wprost do bramy niebios, a oznacza radosną pracę miłości. Wówczas zakonnica poprawia się według rad tych, którzy wzgardzili światem ${ }^{10}$. Znajdujący się po bokach bramy święci Jan Ewangelista - uczy cnoty posłuszeństwa, Piotr - wiary, Paweł - cierpliwości, Jan Chrzciciel - słodyczy. Ale jako wzór do naśladowania, by osiągnąć niebo, postawiona jest przede wszystkim Matka Boska ${ }^{11}$, która już osiągnęła chwałę nieba, co przedstawia scena jej wniebowzięcia w obrazie ołtarza głównego.

Po drugiej stronie ołtarza głównego, w jego płaszczyźnie znajdował się obraz Drzewo genealogiczne św. Brygidy (il. 11), który rozwijał powyższe treści i potwierdzał wyjątkowość tego zakonu w planach bożych. Przesłanie obrazu z punktu widzenia form plastycznych jest oczywiste: założycielką zakonu Najświętszego Zbawiciela jest św. Brygida. Konkluzja ta znajduje potwierdzenie w wizjach świętej zapisanych w regule zakonu:

Chrystus powiada Oblubieniecy swoiey S. Brygidzie pod figurą, że gdy insze winnice to iest Zakony, nie iakim sposobem spustoszały, nową chce szczepić winnicę, to iest nowy zakon, o ktorym chce mieć pilne staranie, żeby mu oddawał wino barzo słodkie y wdzięczne, a Brygida ma bydź winną macicą, przerzeczoney winnicy iego, to iest Fundatorką nowego Zakonu, z ktorego wynidą latorośli barzo pożyteczne ${ }^{12}$.

W obrazie, łodygi mają giętkość wici winorośli, a zakończone są kwiatami lilii, które jednak rosną na twardych łodygach. Takie połączenie motywów ma swoją wymowę symboliczną. W pismach św. Brygidy lilie obrazują wyznawców, zakonnice i zakonników, którzy dążąc do doskonałości naśladują Matkę Bożą.

Drugim miejscem, z którego mniszki widziały wnętrze kościoła był chór dolny. Przebywając w bardzo bliskim sąsiedztwie wizerunku Maryi Wniebowziętej, z niewielkiej odległości oglądały również obrazy stall prezbiterium, ale tylko tę stronę, która odnosił się do pierwszego etapu życia św. Brygidy (il. 19). Przesłanie tych przedstawień było dla nich szczególnie doniosłe. Mówią bowiem o wyjątkowym posłannictwie założycielki ich zakonu w Kościele, przewidzianym dla niej przez samego Boga. Świętej zostało to przekazane w cudowny sposób podczas

\footnotetext{
${ }^{10}$ Skarby Niebieskich Taiemnic, ks. 3 rozdz. 12, s. 178.

${ }^{11}$ Kwiatkowska-Frejlich, Funkcje potrydenckiej sztuki kościelnej, s. 111-115.

${ }^{12}$ Reguta S. Salwatora, s. 8-12.
} 
przeżyć mistycznych. Oglądając na co dzień te obrazy, zakonnice utwierdzały się w przekonaniu, że ich reguła zakonna ma źródło nadprzyrodzone.

Ojcowie duchowni zakonnic, którzy nie byli wówczas brygidianami, gdyż wspólnota męska w klasztorze lubelskim została już skasowana, korzystali ze znajdujących się w prezbiterium stall. Badacze tej epoki twierdzą, że istniało wówczas przekonanie, że dokonywała się symboliczna formacja osób, które $\mathrm{w}$ nich siadały zgodnie $\mathrm{z}$ treściami ukazanymi na obrazach $\mathrm{w}$ nie wprawionych ${ }^{13}$. Zauważmy zatem, że obrazy, które ukazują drogę duchowości zakonu brygidiańskiego, są dla ojców przypomnieniem, że zakonnice chcą żyć według założeń szkoły duchowości swojego zakonu, pomimo tego, że oni sami żyją według zasad duchowości swojej wspólnoty.

Nowicjuszki miały swoje miejsce w jedynej już wówczas kaplicy kościoła, o czym świadczą zapiski klasztorne ${ }^{14}$. Ponadto wymowa przedstawień w ołtarzu kaplicy oraz stall tam umieszczonych, ich znaczenie odnosiło się bezpośrednio do kondydatek ${ }^{15}$. Podobnie jak treści obrazów w stallach prezbiterium pozostające w zasięgu ich wzroku, gdyż z tego miejsca, jeszcze przed ostateczną decyzją wstąpienia do klasztoru, mogły oglądać obraz ołtarza głównego ukazujący wniebowzięcie Maryi, Drzewo genealogiczne św. Brygidy, o którym powiedzieliśmy wcześniej, że ukazuje moment decyzji św. Brygidy, zerwania ze swoim świeckim życiem, aby wieźć życie zakonne. W następnych obrazach widzimy ją i jej córkę Katarzynę wkraczające już w nowe życie zakonne. Tę narrację obrazującą zerwanie z życiem świeckim przyszłej zakonnicy, kończy obraz Adoracja krzyża przez śś. Brygide i Katarzynę (il. 13) nad drzwiami wiodącymi do klauzury, w którym zostało powiedziane, że klasztor jest bramą i przedprożem nieba. Pierwszy i ostatni z tych obrazów łączy wspólny motyw. W obrazie głównym grób Maryi, który w przedstawieniach ukazujących unoszoną ją do nieba przez anioły, oznacza „wrota śmierci i bramę Niebios"16. Wypełniony jest kwiatami, co odnosi się do jednej z przyczyn jej wniebowzięcia: doskonałości i nadzwyczajnych cnót, które praktykowała „między cierniem, między uciskami”" ${ }^{17}$. Natomiast w obrazie Adoracja krzyża przez śś. Brygidę i Katarzynę - który jest alegorią zakonu brygidiańskiego,

${ }^{13}$ J. Pietrusiński, Średniowieczna encyklopedia opactwa w Pelplinie, w: Średniowiecze. Studia o kulturze, red. Julian Lewański, Warszawa 1961, s. 80-81. Stalle kościelne często były ozdabiane personifikacjami cnót, „co miało ilustrować obecność duchowych i etycznych wartości w życiu wiernych, zarówno duchownych jak i fundatorów kościoła”. E. Zapolska, Cnoty teologiczne $i$ kardynalne, Kraków 2000, s. 163. Ewa Zapolska nie powołuje się na źródło tych informacji.

${ }^{14}$ PAN Kraków, Catalog albo porzadek do zakonu przyjścia i śluby P[anu] B[ogu]oddania zakonnych panien reguly św. Brygidy przy kościele P. Maryjej w Lublinie, po wizytacjej jaśnie oświeconego książęcia jm. ks. Jerzego Radziwiłta, kardynała św. Kościoła rzymskiego, biskupa krakowskiego, przez wielebna pannę Agnieszkę Jastkowska, ksienię klasztoru tego, uczyniony w roku Pańskim 1596 w miesiacu grudniu, rps. 2335, k.157.

${ }^{15}$ Kwiatkowska-Frejlich, Funkcje potrydenckiej sztuki kościelnej, s. 191-216.

${ }^{16}$ U. Zielińska, Ikonografia I obrazu Wniebowzięcia z Warty, „Ikonotheka”, 1991, s. 99.

${ }^{17}$ Mowa Anielska, w: Skarby Niebieskich Taiemnic to iest Ksiegi Obiawienia niebieskiego Świętey Matki Brygitty Z rodzaju Królewskiego Xiężney Nerycki ze Szwecyey Fundatorki Reguly S. Salvatora z łacinskich na polskie przełożone przez zakonnika Braci Mniejszych Oyców Bernardynów za pozwoleniem starszych, Zamość 1698, s. 738-739. 
kwiaty symbolizują wysiłek św. Brygidy, jej córki oraz zakonnic brygidiańskich w zdobywaniu cnót. Pamiętajmy, że końcowym etapem obrzędu publicznej konsekracji zakonnicy brygidiańskiej było wprowadzenie za klauzurę nowej mniszki, która wówczas leżała na marach, na znak, że umarła dla świata ${ }^{18}$. W przestrzeni lubelskiego kościoła przejście to znajdowało się pod tym właśnie obrazem.

Nowicjuszki ze swojego miejsca w kaplicy widziały również przedstawienia ukazujące wysiłki ascetyczne św. Brygidy (il. 20). Od czasów, o których tu mówimy klasztory były poddawane reformom trydenckim. W konwencie lubelskim nowicjat objęty był takim samym prawem klauzury, jak reszta wspólnoty ${ }^{19}$. Ale ta praktyka nie była zgodna z ustawami własnymi brygidek. Reguła „nie przewidywała w ogóle okresu formacji w nowicjacie, a tylko próbę intencji przed przyjęciem. (...) Należało przez cały rok odsyłać zgłaszającą się kandydatkę od furty, a jeżeli mimo to trwała w zamiarze wstąpienia, po roku odbywała się uroczystość, podczas której miały miejsce i obłóczyny i profesja zakonna i konsekracja. Do klauzury wprowadzano więc już od razu pełnoprawną mniszkę" ${ }^{20}$.

Kościoły brygidiańskie były otwarte dla wiernych, którzy gromadzili się w jedynej w tym kościele nawie bocznej. Ze swojego miejsca mogli oglądać tylko część stall z obrazami ukazującymi pierwszą część życia św. Brygidy - sceny dokumentujące fakt wybrania ją przez Boga oraz Święta Brygida w otoczeniu świętych w obecności Boga Ojca (il. 9), który pouczał wiernych o życiu zakonnic w klasztorze brygidiańskim. To w jaki sposób realizują drogę doskonałości naśladując w tym Maryję. Ołtarz główny ze sceną wniebowzięcia obrazował cel życia każdego człowieka.

Ta krótka analiza pokazuje, że przedstawienia cyklu życia św. Brygidy, układające się w historyczną narrację, przekazywały dodatkowe treści, które w sposób szczególny były istotne dla modlących się w kościele różnych grup wiernych. Działo się tak dlatego, że naprawdę widziały tylko ich fragment, oglądając części stall z określonych, sobie przeznaczonych miejsc w kościele. Mniszki żyjące w klasztorze po to, aby osiągnąc zbawienie wieczne, widziały obrazy wokół ołtarza głównego, które przekonują, że podjęły właściwą drogę duchowości brygidiańskiej. Na te obrazy mogli patrzeć również ojcowie duchowni zakonnic. Ich miały przekonać o skuteczności tej drogi duchowości, dlatego, pomimo, że sami byli bernardynami albo dominikanami, nie powinni wprowadzać ze swej strony żadnych zmian, gdyż brygidki chcą żyć według swojej własnej tradycji. Nowicjuszkom zostały postawione przed oczy trudy życia zakonnego, aby zniechęcić je do wstąpienia do klasztoru, co było jak wiemy, zgodne z postępowaniem $\mathrm{z}$ nimi, przed reformami trydenckimi. Była to więc próba nawiązania do dawnych zwyczajów, które wypływały z zaleceń św. Brygidy.

${ }^{18}$ J.K. Wietz, P. Bohmann, Rys historyczny zgromadzeń zakonnych obojej ptci wraz z rycerskiemi zakonami i orderami państwowymi, t. 2, Zakony żeńskie, przeł. ks. Beniamin, Warszawa 1848, s. 84 .

${ }^{19} \mathrm{M}$. Borkowska, Miscellanea brygidiańskie: dwie fazy reformy potrydenckiej klasztoru lubelskiego, „Nasza Przeszłość”, 89 (1998) s. 138.

${ }^{20}$ Tamże, s. 127. 
Z powyższych ustaleń wynika, że autorem programu ikonograficznego zespołu obrazów kierowało przekonanie, że brygidiańska droga duchowości nie potrzebuje żadnych zmian. Nie dziwi zatem, że spośród licznych cudów, które dokonały się za przyczyną św. Brygidy w społeczności chrześcijańskiej po jej śmierci, do omawianego cyklu wybrano tylko jeden (il. 18), który przypomina, że jedną z zasadniczych cech zakonnicy brygidiańskiej jest posłuszeństwo słowom zakonodawczyni. A za podstawowy argument uznano, o czym mówią obrazy pierwszej części cyklu, dostępne mniszkom, ojcom duchownym, a nawet wiernym modlącym się w kościele, że Brygida była narzędziem w ręku Boga, i realizowała boże zamierzenia.

Czyżby poddające się w tym czasie reformom trydenckim brygidki lubelskie, tak naprawdę pragnęły pozostać przy swoich dawnych zwyczajach? Małgorzata Borkowska, która badała stopień zaawansowania zmian w klasztorze za czasów ksieni Agnieszki Jastkowskiej - poprzedniczki Doroty Firlejówny - skonkludowała, że w kwestii nowicjatu, reguły i modlitwy myślnej, Jastkowska stosowała „długo i cierpliwie (...) bierny opór jako jedyną broń” ${ }^{21}$. Według M. Borkowskiej zgromadzenie lubelskie ostatecznie zreformowało się w duchu potrydenckim dopiero na początku XVIII w. za czasów ksieni Teofili Dłużewskiej (1720-1737), co wnosi z tekstu, który brygidki sporządziły w 1733 roku. Wprowadzał on nowe rozporządzenia, obejmujące różne kwestie dotyczące życia wspólnoty, w pełni już zaakceptowane przez wszystkie zakonnice. M. Borkowska wnosi to z częstego użycia słowa lub końcówki $m y^{22}$. W tej deklaracji reformy: pojawia się m.in. wzmianka o medytacji, na którą przeznacza się wyraźnie określony czas wspólny. Borkowska przypuszcza, że „byłaby to chyba chronologicznie najwcześniejsza wzmianka źródłowa o medytacji w tym klasztorze" ${ }^{23}$. Przyznaje jednak, że kwestia przyjmowania reform przez wspólnotę lubelską nie jest jasna. W tym samym tekście bowiem mowa jest o rekolekcjach - osiągnięcie epoki potrydenckiej które nie były chyba nowością w tym klasztorze; ,jeśli należało w nim upominać siostry odbywające to ćwiczenie, aby pomimo potrzeby szczególnego skupienia, jadały we wspólnym refektarzu" 24 .

W obecnej sytuacji, gdy brak dokumentów, które by nie budziły wątpliwości, zaprezentowane w tym tekście wyniki analizy układu obrazów w stallach kościoła, niech będą kolejnym przyczynkiem w kwestii stanu reformy trydenckiej w klasztorze brygidek lubelskich za czasów ksieni Doroty Firlejówny.

Słowa kluczowe: ikonografia brygidiańska, brygidki lubelskie, św. Brygida Szwedzka, retoryka przekazu wizualnego, kościół pw. Matki Boskiej Zwycięskiej

\footnotetext{
${ }^{21}$ Tamże, s. 142-143.

${ }^{22}$ Tamże, s. 144.

${ }^{23}$ Tamże, s. 143, 147.

${ }^{24}$ Tamże, s. 148.
} 


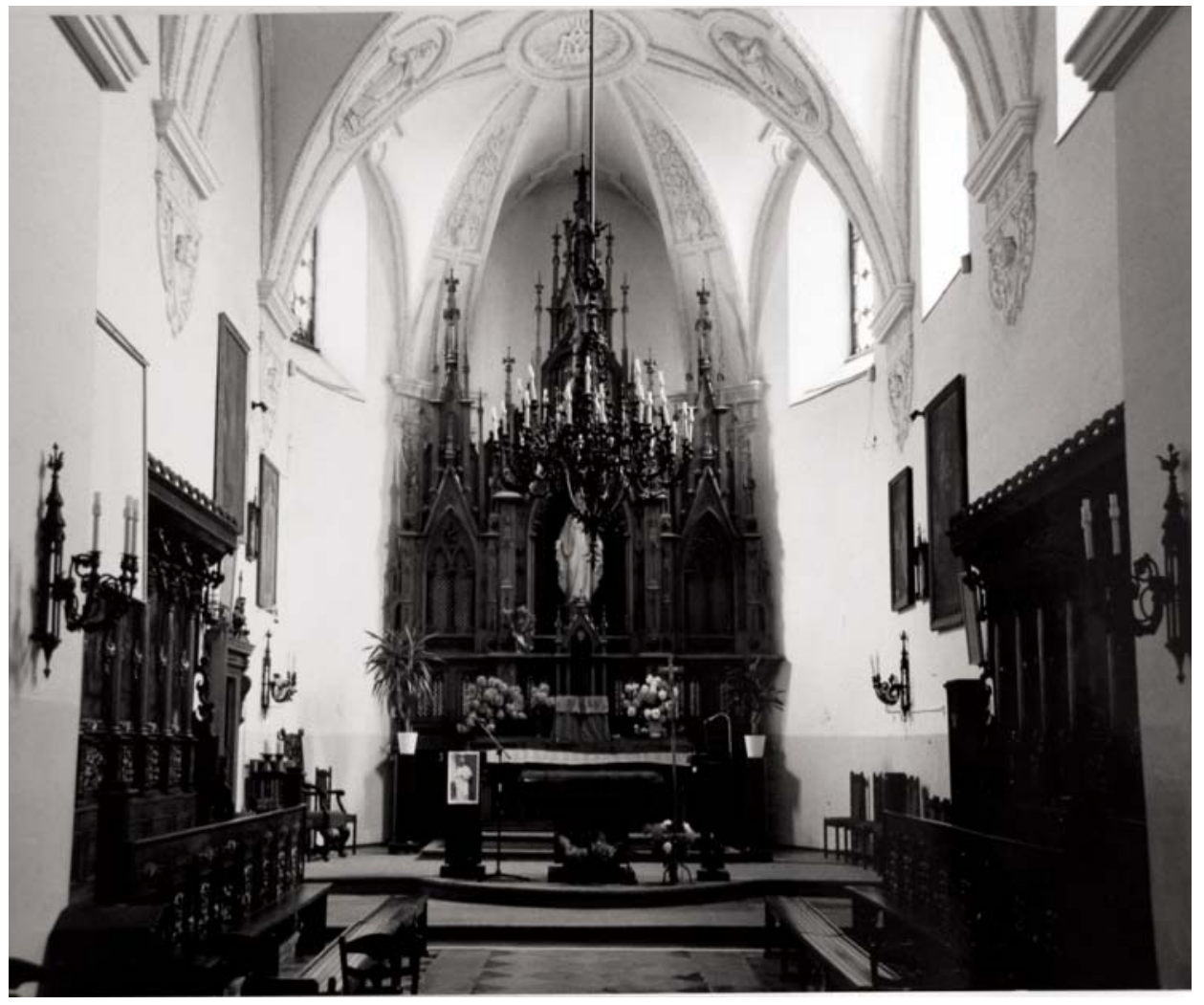

Fot. 1. Stalle w prezbiterium, stan obecny. F. A. Frejlich.

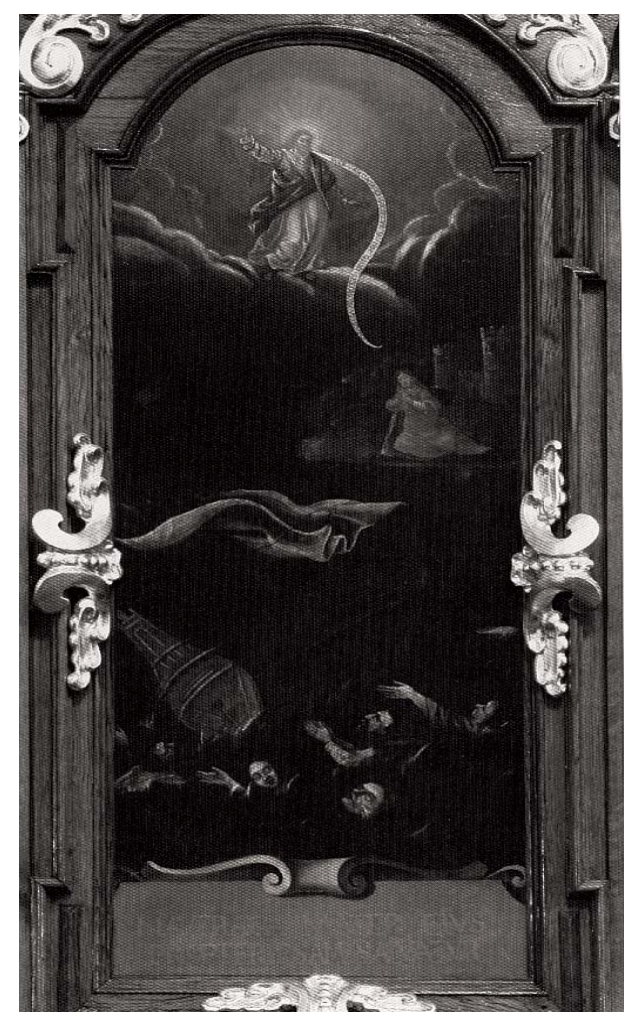

Fot. 2. Cudowne uratowanie z topieli matki św. Brygidy. Fot. Andrzej Frejlich. 


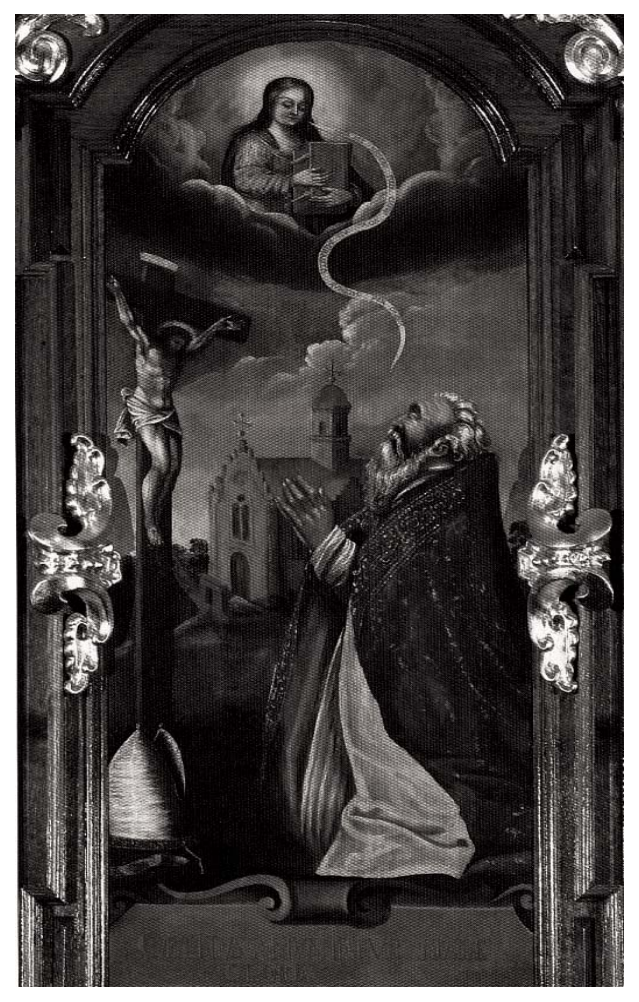

Fot. 3. Ogłoszenie proboszczowi parafii rodziców św. Brygidy jej narodzin. Fot. Andrzej Frejlich.

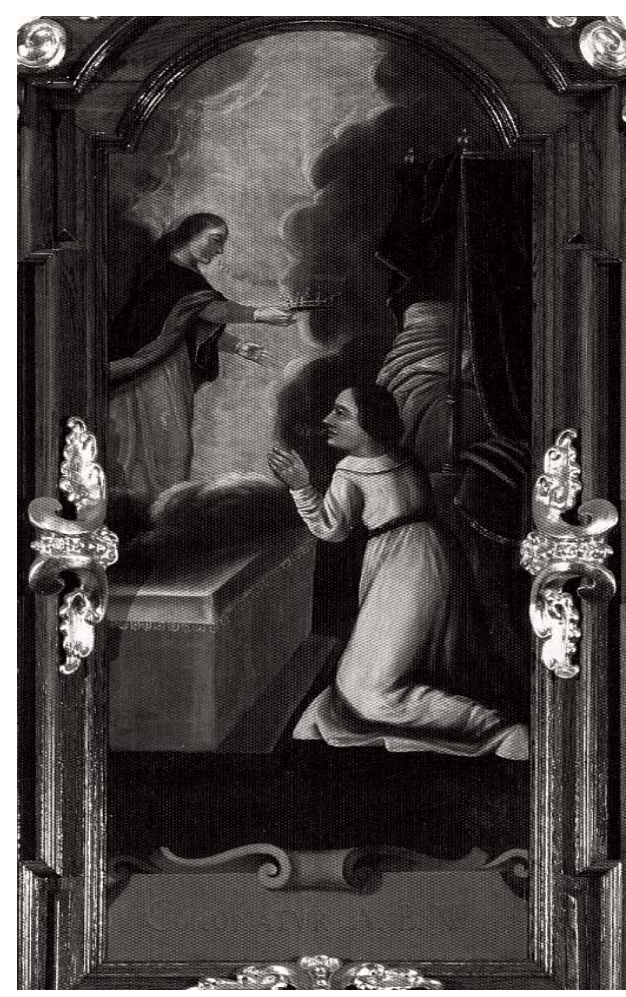

Fot. 4. Przyjęcie korony niebieskiej. Fot. Andrzej Frejlich. 


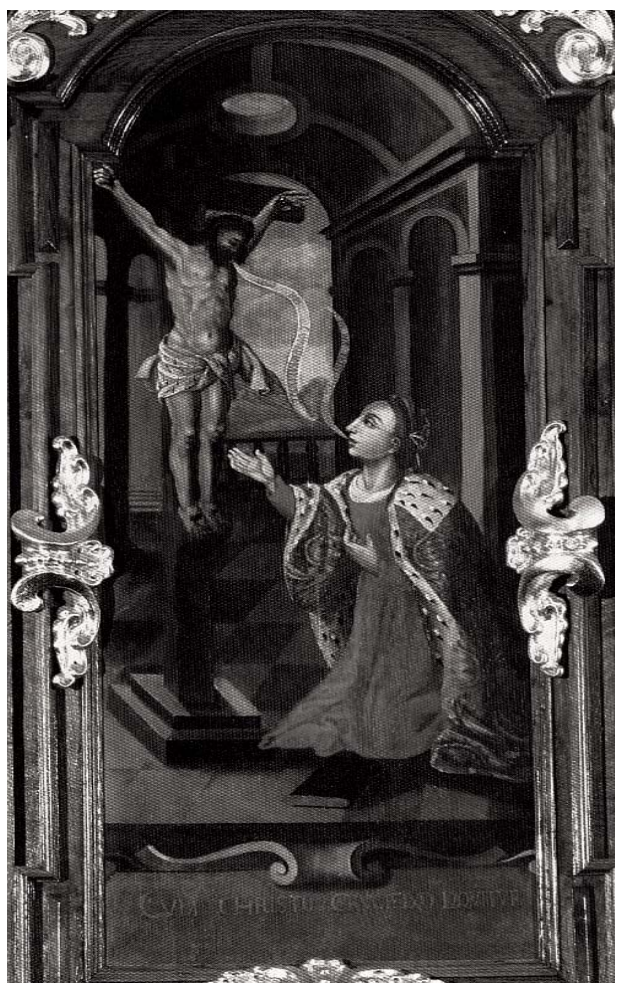

Fot. 5. Wizja z ukrzyżowanym Chrystusem. Fot. Andrzej Frejlich.

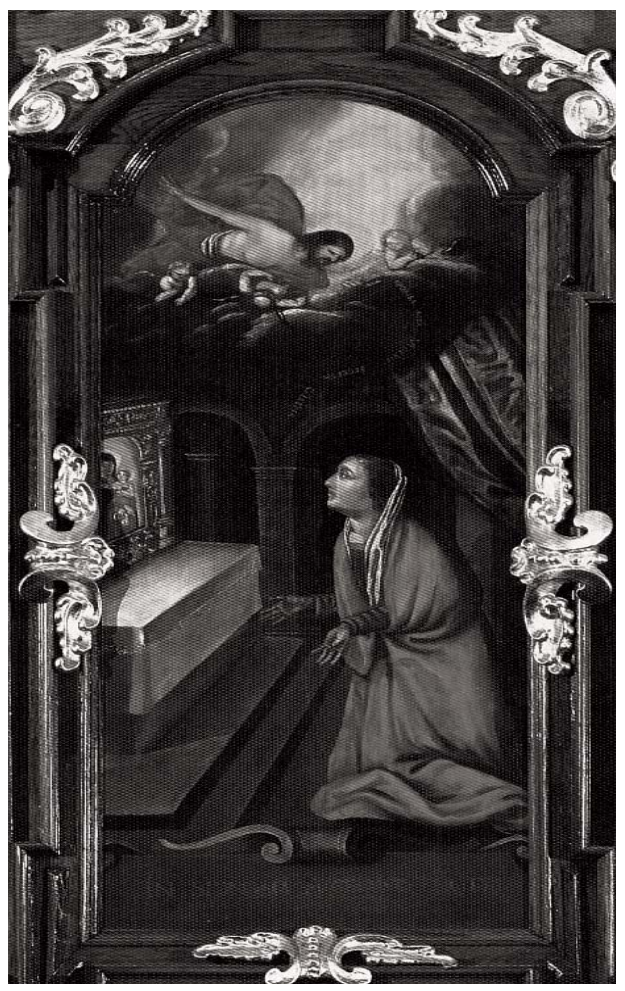

Fot. 6. Objawienie po śmierci męża. Fot. Andrzej Frejlich. 


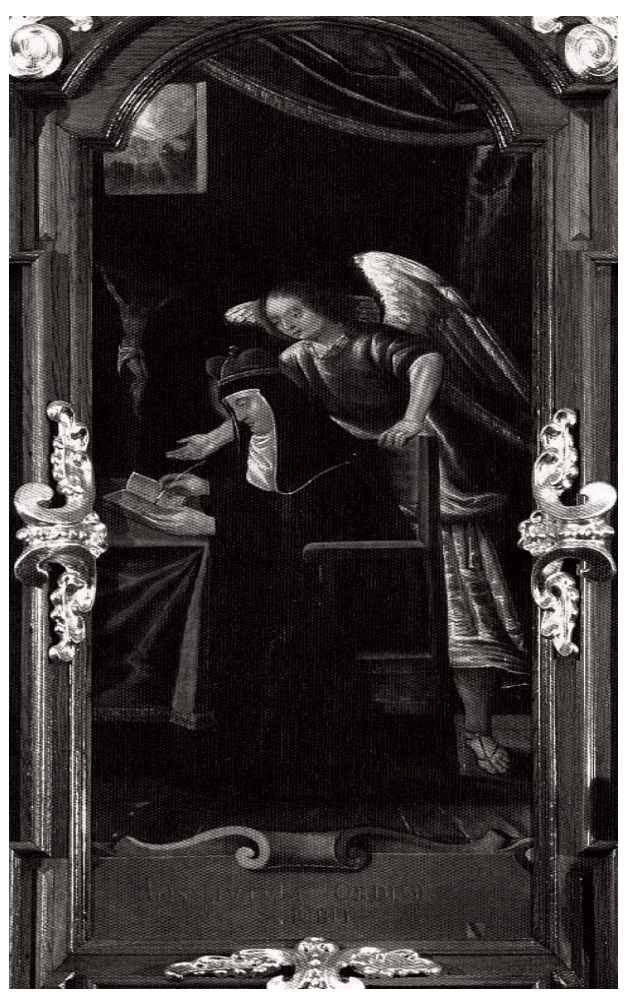

Fot. 7. Brygida spisuje regułę zakonu. Fot. Andrzej Frejlich.

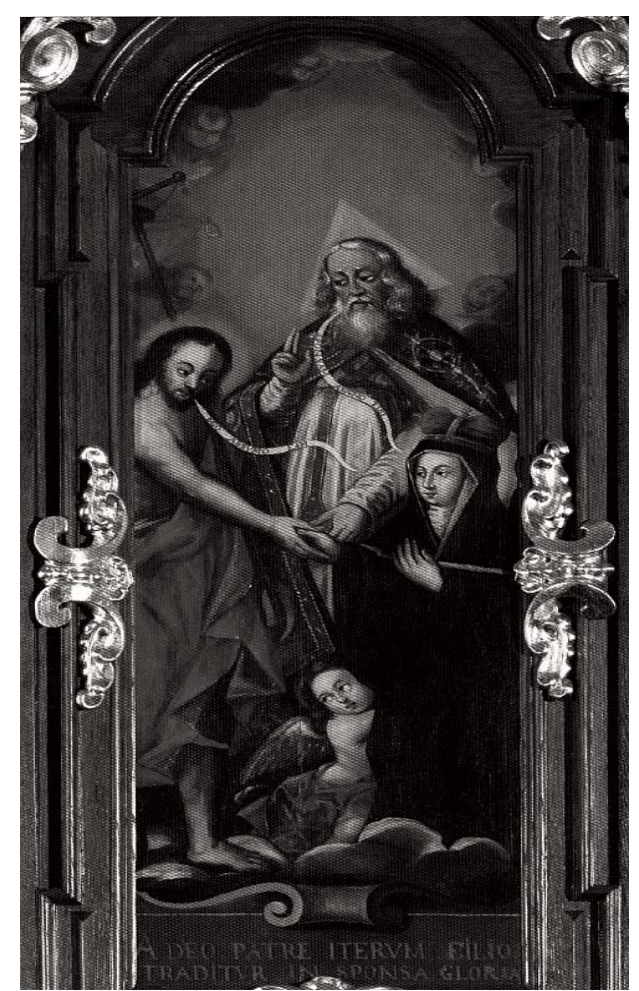

Fot. 8. Mistyczne zaślubiny św. Brygidy. Fot. Andrzej Frejlich. 


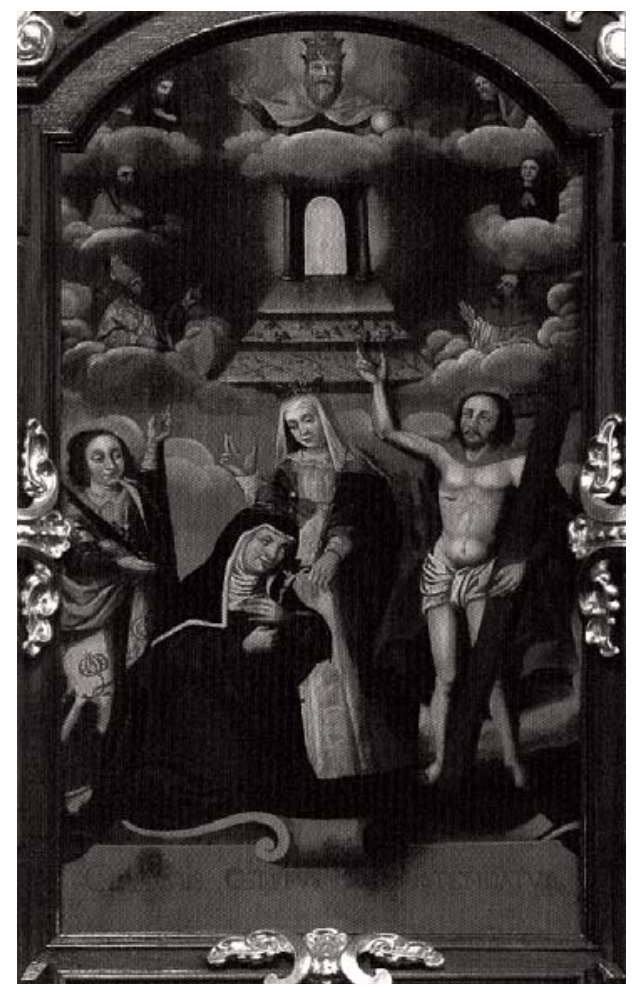

Fot. 9. Święta Brygida w otoczeniu świętych w obecności Boga Ojca. Fot. Andrzej Frejlich.

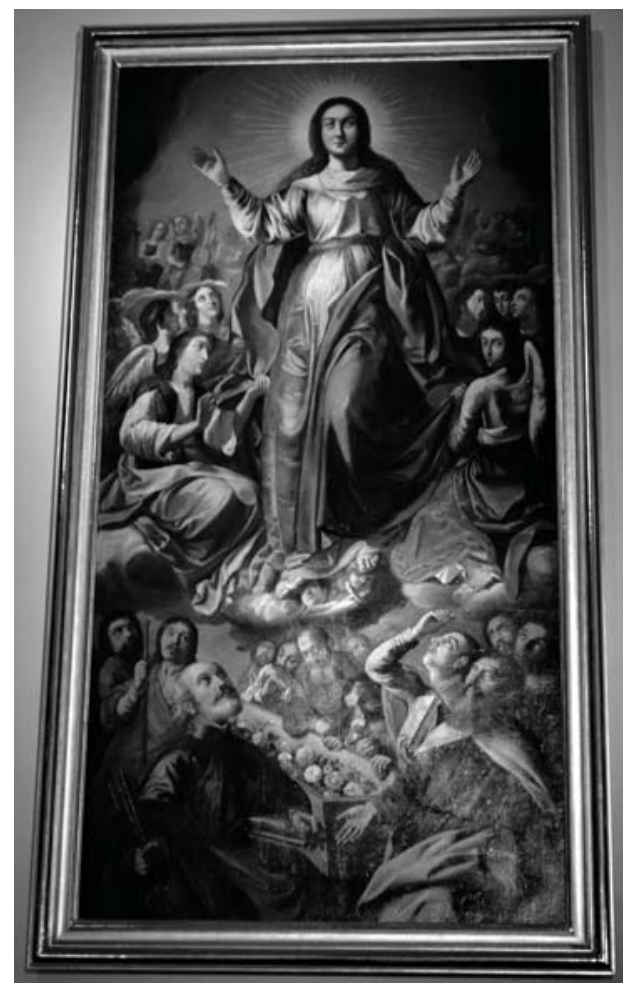

Fot. 10. Wniebowzięcie Maryi, dawniej w ołtarzu głównym. Fot. Andrzej Frejlich. 


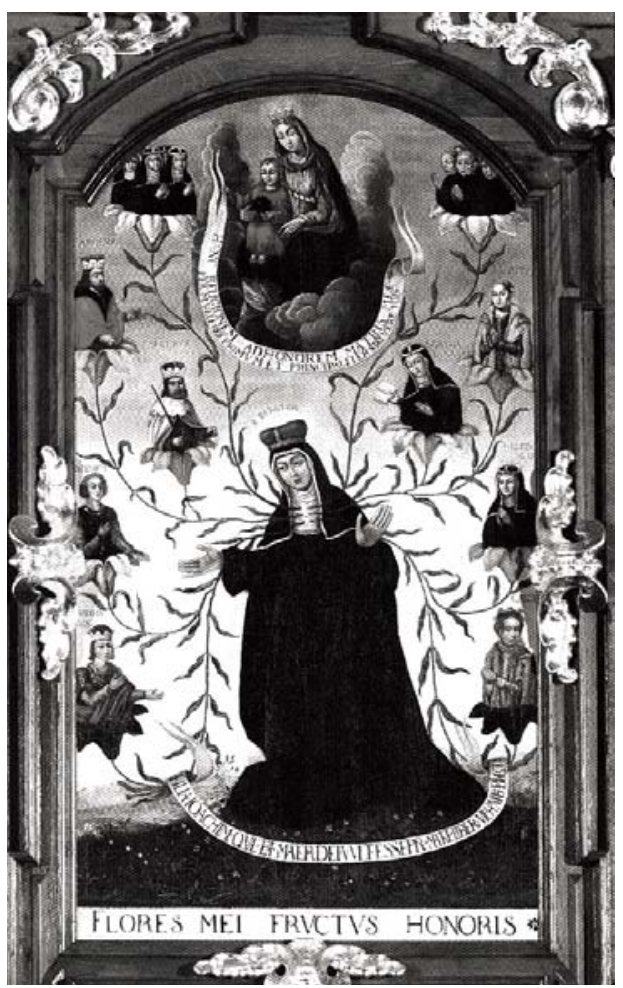

Fot. 11. Drzewo genealogiczne św. Brygidy. Fot. Andrzej Frejlich.

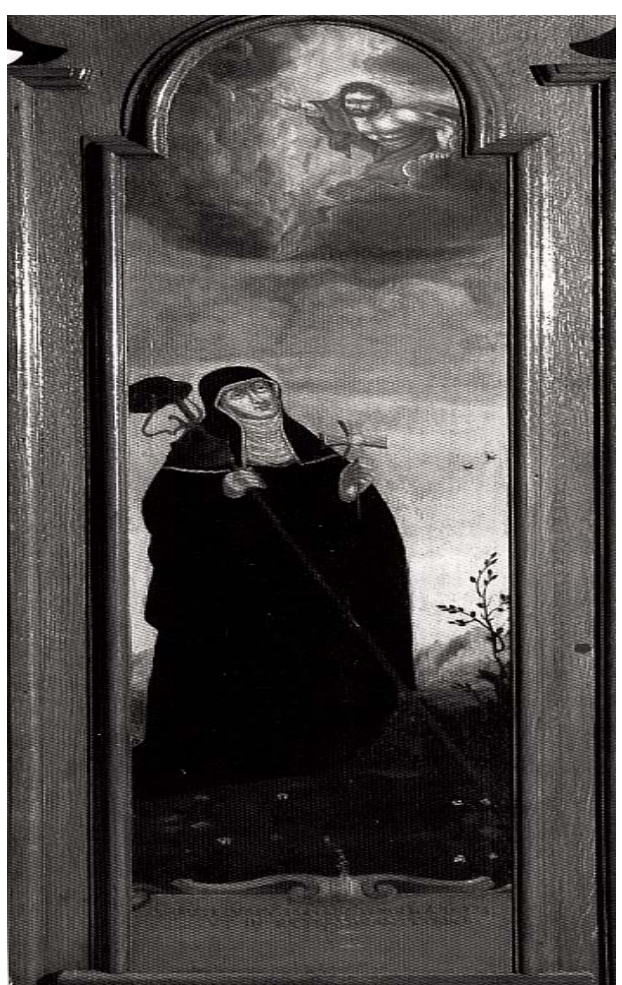

Fot. 12a. Św. Brygida w drodze do Rzymu. Fot. Andrzej Frejlich.

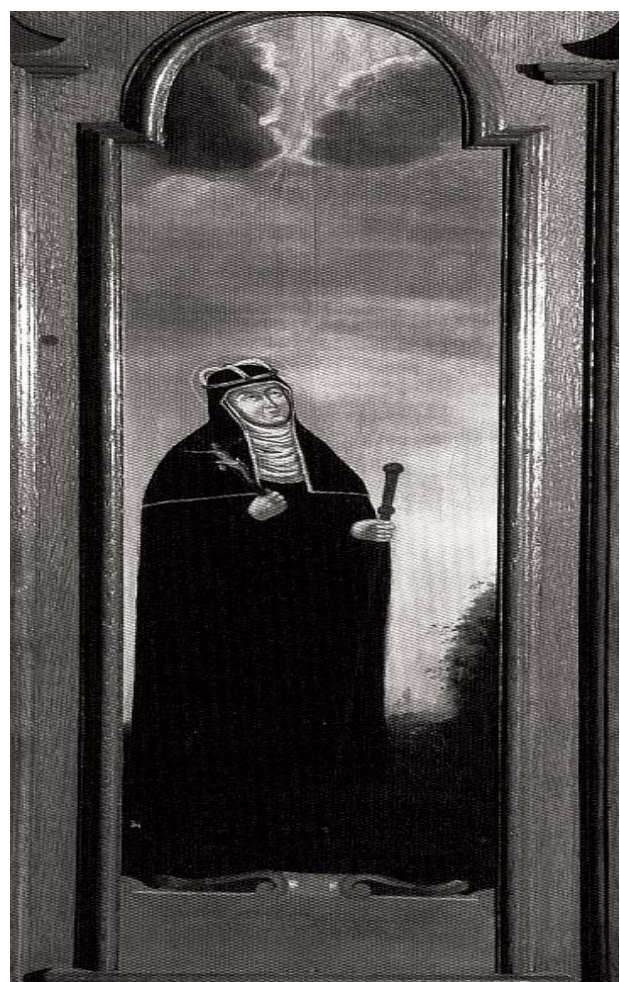

Fot. 12b. Św. Katarzyna w drodze do Rzymu. Fot. Andrzej Frejlich. 


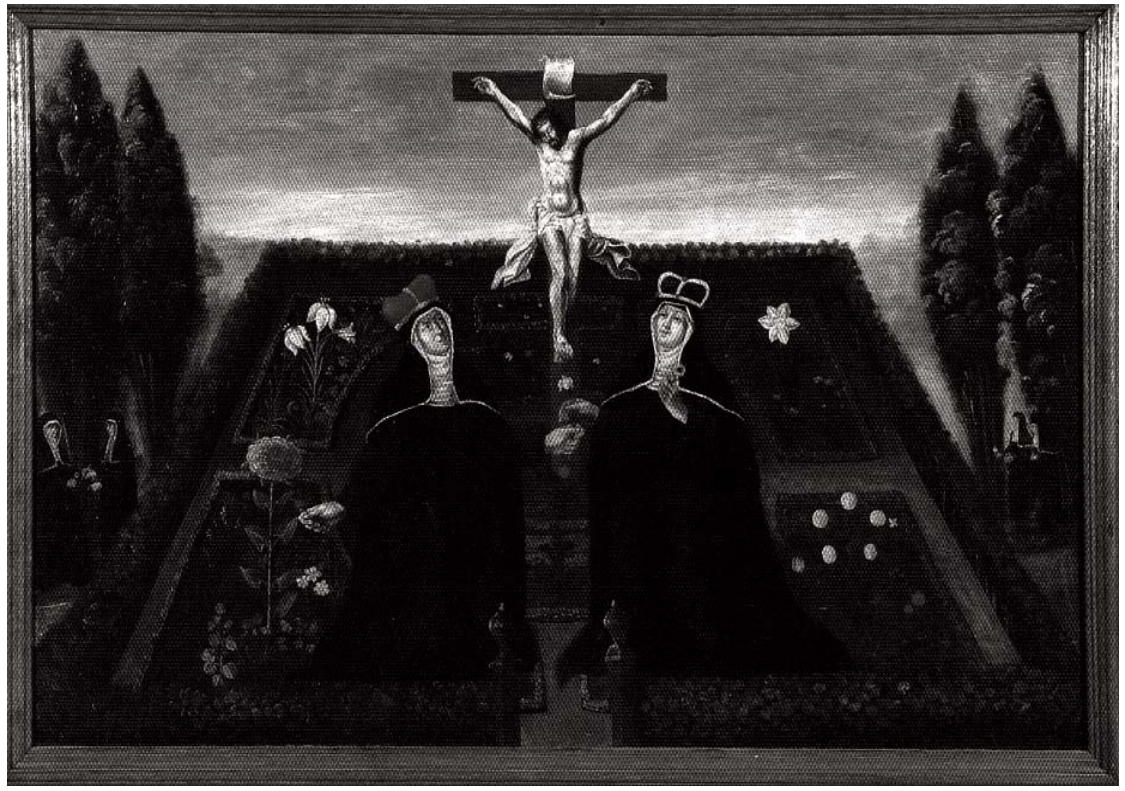

Fot. 13. Adoracja krzyża przez śś. Brygidę i Katarzynę. Fot. Andrzej Frejlich.

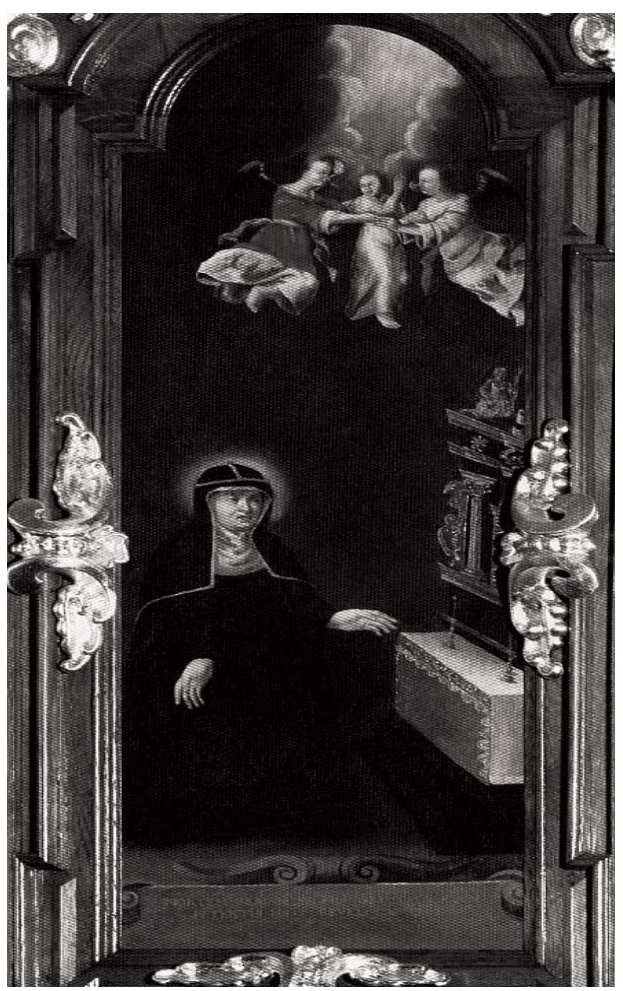

Fot. 14. Wizja po śmierci syna Karola. Fot. Andrzej Frejlich. 


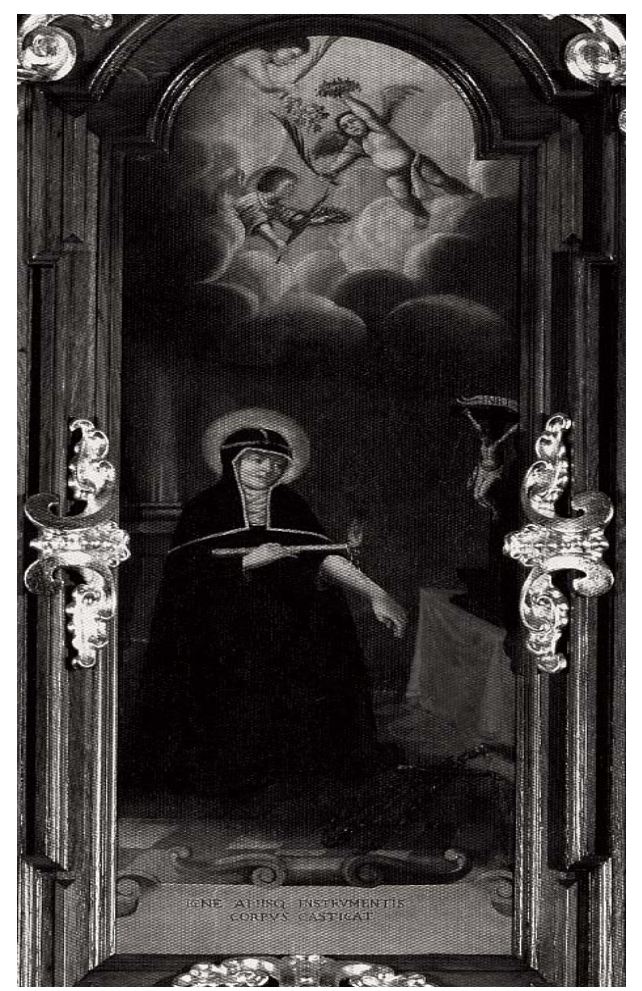

Fot. 15. Umartwianie się świętej Brygidy. Fot. Andrzej Frejlich.

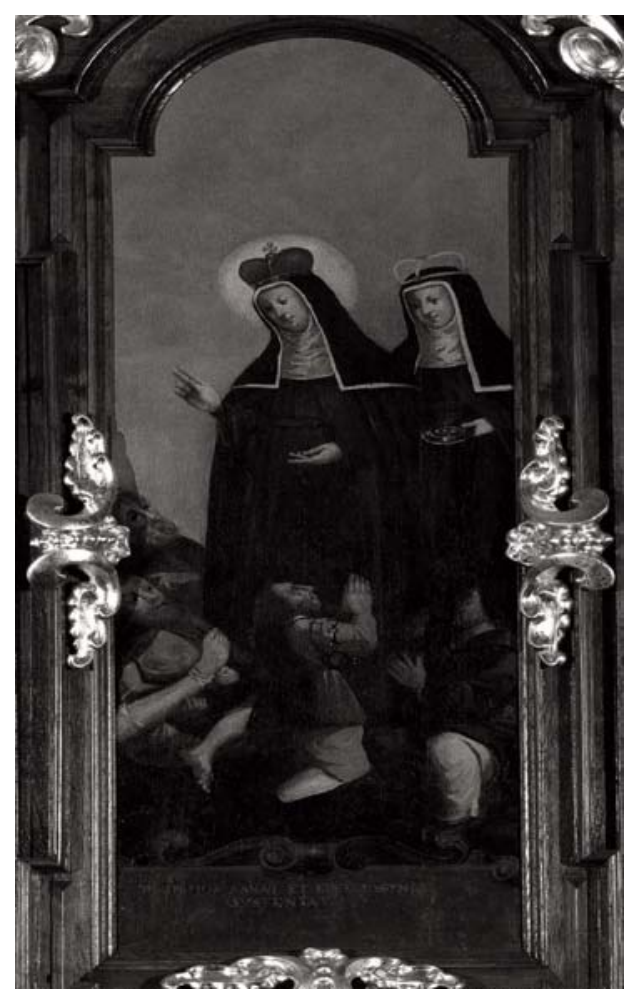

Fot. 16. Rozdawanie jałmużny przez św. Brygidę. Fot. Andrzej Frejlich. 


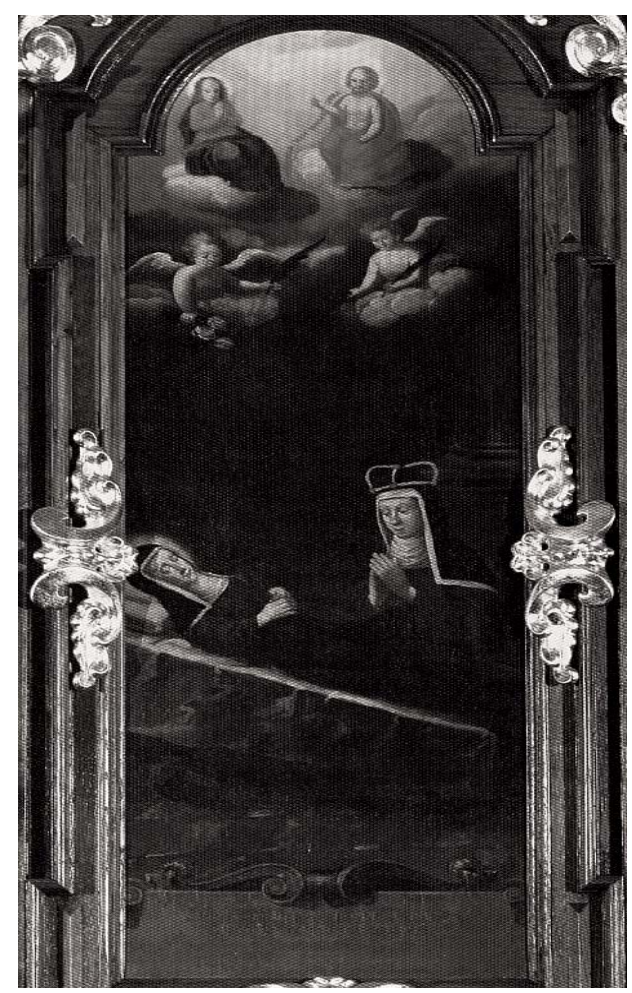

Fot. 17. Śmierć św. Brygidy. Fot. Andrzej Frejlich.

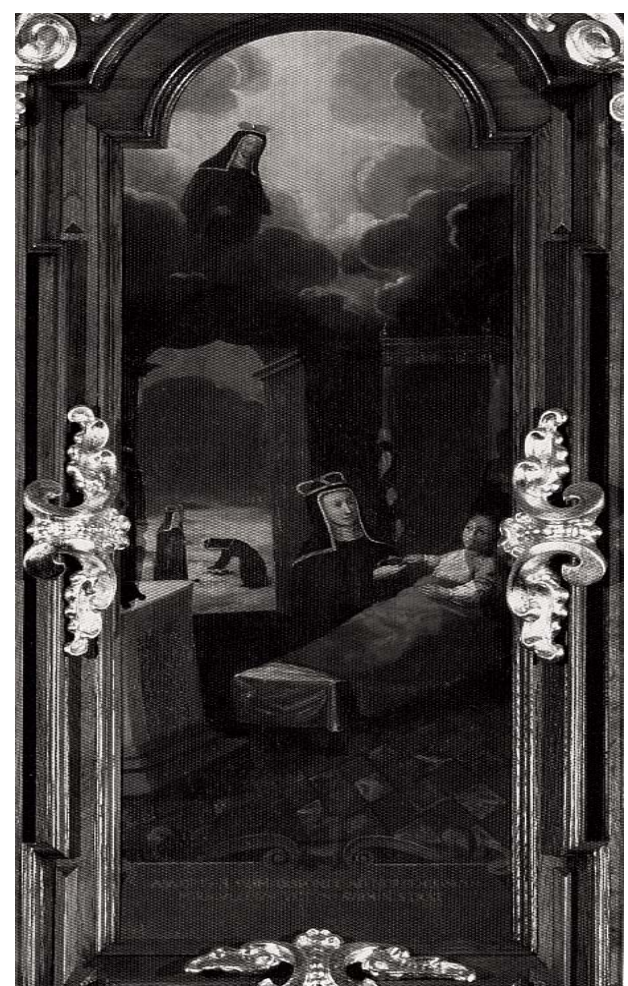

Fot. 18. Święta Brygida przygotowującą swoją prawnuczkę na śmierć. Fot. Andrzej Frejlich. 


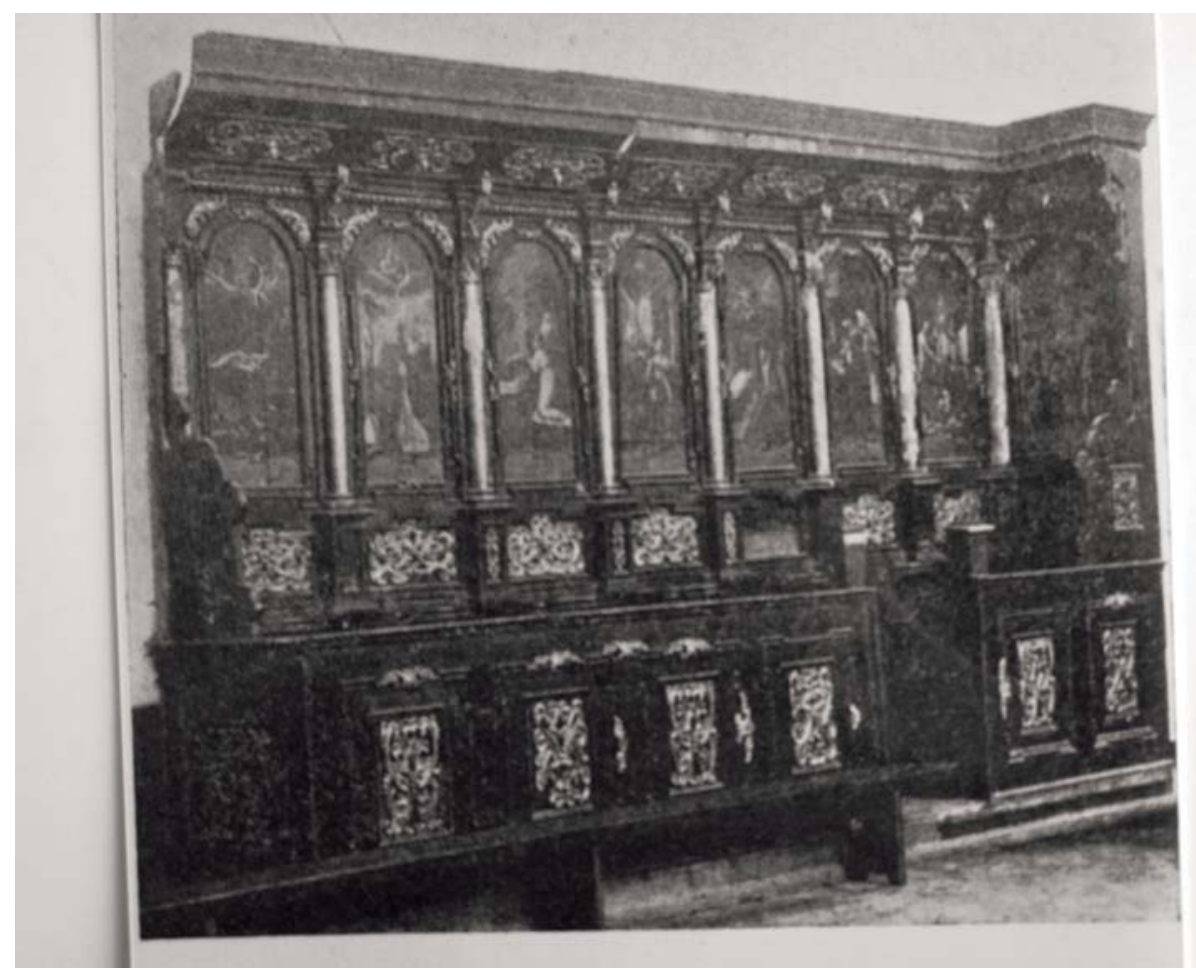

Fot. 19. Pierwotny wygląd stall w prezbiterium, strona północna. J. Smoliński, Kościót pp. Brygidek, później pp. Wizytek w Lublinie i odkryte malowidła ścienne z XV wieku, „Sprawozdania Komisji do Badania Historii Sztuki w Polsce”, 9 (1915); strona południowa, M. Ronikierowa, Ilustrowany przewodnik po Lublinie, cz.1, Warszawa 1901, zdjęcie ze s. 138.

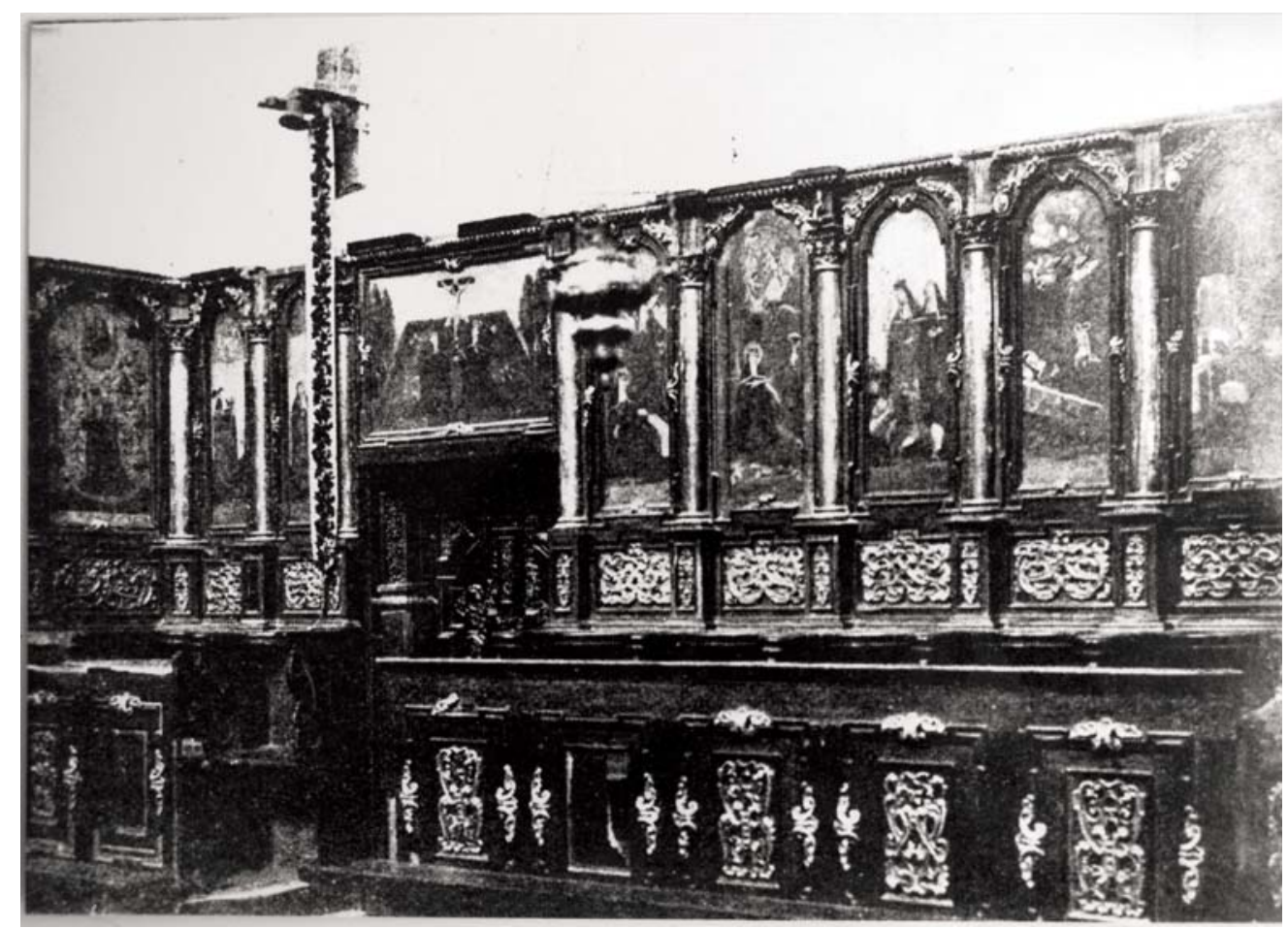

Fot. 21 Pierwotny wygląd stall w prezbiterium strona południowa, M. Ronikierowa, Ilustrowany przewodnik po Lublinie, cz.1, Warszawa 1901, zdjęcie ze s. 138. 


\section{Źródla}

\section{BIBLIOGRAFIA}

Catalog albo porządek do zakonu przyjścia i śluby $\mathrm{P}$ [anu] B[ogu]oddania zakonnych panien reguły św. Brygidy przy kościele P. Maryjej w Lublinie, po wizytacjej jaśnie oświeconego książęcia jm. ks. Jerzego Radziwiłła, kardynała św. Kościoła rzymskiego, biskupa krakowskiego, przez wielebną pannę Agnieszkę Jastkowską, ksienię klasztoru tego, uczyniony w roku Pańskim 1596 w miesiącu grudniu, rps. PAN Kraków 2005.

Poczyna się żywot skrócony ukochaney Oblubienice Chrystusowey ś. Brygitty, z krolestwa szwedzkiego, zawieraiący w sobie pewne Obiawienia Boskie z niektorymi cudami, w: Skarby Niebieskich Taiemnic.

Reguła S. Salwatora podana ś. Brygidzie z rewelacyj Xiąg iej z łac. na polskie przetłum. (Wiktoria Niemierzanka) z reguły Augustyna ś... ustawami zakonu tejże ś. Brygidy, Kraków 1673.

Skarby Niebieskich Taiemnic to iest Księgi Obiawienia niebieskiego Świętey Matki Brygitty Z rodzaju Królewskiego Xiężney Nerycki ze Szwecyey Fundatorki Reguły S. Salvatora $\mathrm{z}$ łacinskich na polskie przełożone przez zakonnika Braci Mniejszych Oyców Bernardynów za pozwoleniem starszych, Zamość 1698.

\section{Opracowania}

Borkowska M., Miscellanea brygidiańskie: dwie fazy reformy potrydenckiej klasztoru lubelskiego, „Nasza Przeszłość”, 89 (1998) s. 125-150.

Kwiatkowska-Frejlich J., Funkcje potrydenckiej sztuki kościelnej. Nowożytny wystrój kościoła brygidek w Lublinie, Lublin 2009.

Pietrusiński J., Sredniowieczna encyklopedia opactwa w Pelplinie, w: Średniowiecze. Studia o kulturze, red. J. Lewański, Warszawa 1961, s. 51-92.

Smoliński J., Kościół pp. Brygidek, później pp. Wizytek w Lublinie i odkryte malowidła ścienne z XV wieku, „Sprawozdania Komisji do Badania Historii Sztuki w Polsce”, 9 (1915) szp. 269-299.

Wietz J.K., Bohmann P., Rys historyczny zgromadzeń zakonnych obojej płci wraz z rycerskiemi zakonami i orderami państwowymi, t. 2, Zakony żeńskie, przeł. ks. Beniamin, Warszawa 1848.

Zapolska E., Cnoty teologiczne i kardynalne, Kraków 2000.

Zielińska U., Ikonografia I obrazu Wniebowzięcia z Warty, „Ikonotheka” 1991, s. 83-114. 


\title{
ST BRIDGET- THE CYCLE OF PAINTINGS IN THE CHURCH OF THE ASSUMPTION OF THE BLESSED VIRGIN MARY OF VICTORY IN LUBLIN
}

\begin{abstract}
Summary
In the first half of the17th century, the stalls with the paintings in their backs showing episodes of the life of St. Bridget of Sweden were introduced into the chancel of the church of the Bridgettines in Lublin. The first series depicted seven paintings on the north wall and one on the east one at the high altar, the other series was made up of one picture on the east wall and six in southern wall. However, those who were present in the church watched only the fragment of the cycle, as they were allowed to be only in the area especially marked for them.

A brief analysis of the iconographic representations shows that the scenes of the cycle, arranged in historical narrative, additionally provided the content that in the particular fragment was intended for specific groups. The nuns staying in the upper or lower choir saw the images around the high altar; the pictures both encouraged the Bridgettines to take the right path of spirituality and showed that the monastic rule was given to St. Bridget by Jesus in a supernatural way. Nuns' fathers confessors - the Bernardines or Dominicans benefited from the stalls in the chancel - they could watch the cycle as a whole and appreciate the effectiveness of Bridgittines' path of spirituality. Novices had their place in the only chapel of the church. They looked at those fragments which depicted the hardships of religious life; the aim of the images was to discourage novices from joining the monastery, which was in accordance with the traditional attitude towards them in that religious order. The faithful who gathered in the only side aisle in that church could see the paintings which showed the life of the Bridgettines.
\end{abstract}

Keywords: Bridgettine iconography, visual rhetoric 